\title{
Imaging of serous psammomacarcinoma of ovary with subcutaneous deposits: A case report
}

\author{
Nagaraj Diwakar, Ravindra B Kamble, Jagannath Dixit', Dashavara Sreekantaiah Gangadhara², \\ Roshan V Shetty \\ Departments of Radiology, 'Oncology and ${ }^{2}$ Pathology, BGS Global Hospital, Bangalore, Karnataka, India
}

Correspondence: Dr. Ravindra B. Kamble, Department of Radiology, BGS Global Hospitals, Uttarahalli Road, Kengeri, Bangalore - 560060 , Karnataka, India. E-mail: drravindra31@rediffmail.com

\begin{abstract}
Serous psammomacarcinoma of ovary is a rare ovarian carcinoma. We present the imaging features of this condition in a patient with a probable metastatic subcutaneous nodule.
\end{abstract}

Key words: Computed tomography; ovary; psammoma bodies

\section{Introduction}

Serous psammomacarcinoma of ovary is a rare and infrequently described variant of ovarian cancer, characterized histologically by the presence of psammoma bodies. ${ }^{[1]}$ We present the imaging features in one such case that was associated with subcutaneous nodules. ${ }^{[1]}$ Till date, as per our knowledge, only 28 case reports have been published. ${ }^{[2]}$ These carcinomas respond well to chemotherapy, and recurrence of disease after surgical resection is reported to below. ${ }^{[3]}$

\section{Case Report}

A 54-year-old female presented with a history of vague abdominal discomfort and loss of appetite for the last 8 months. She had also noticed increase in abdominal girth and loss of weight. Her routine blood investigations were normal. A computed tomography (CT) scan showed

\begin{tabular}{|l|l|}
\hline \multicolumn{2}{|c|}{ Access this article online } \\
\hline Quick Response Code: & \\
\hline & Website: \\
\hline & www.ijri.org \\
\cline { 2 - 3 } & \\
\hline
\end{tabular}

heavily calcified abdominopelvic mass lesions, which were more in the pelvis, and multiple calcified nodules scattered throughout the abdomen (over the liver surface, ligamentum teres, lesser sac, and in both paracolic gutters) [Figure 1]. There was an incidental Morgagni hernia with calcified nodules within [Figure 2]. There was moderate ascites. Calcified subcutaneous nodules were noted in both gluteal regions [Figure 3]. A diagnosis of serous psammomacarcinoma of ovary was made on the basis of the imaging findings. The CA 125 level was elevated, with a value of 33,231 $\mathrm{U} / \mathrm{ml}$ (normal 0-35 U/ml). Biopsy taken from the pelvic mass showed all the classic features of serous psammomacarcinoma of ovary. There were gross psammoma bodies in the biopsy specimen, with moderate desmoplasia and stromal invasion of the tumor. Tumor cells also showed minimal pleomorphism, with mildly increased mitosis and signet cells [Figure 4].

\section{Discussion}

Serous psammomacarcinoma of ovary is a rare tumor presenting between 36 and 76 years of age. ${ }^{[3,4]}$ It commonly arises from the ovary but is also known to arise from the peritoneum. ${ }^{[5]}$ It may mimic a calcified fibroma if the lesion is restricted to the pelvis. ${ }^{[2]}$ Histologically these tumors show classical psammoma bodies. Pathophysiologically, psammoma bodies are formed by deposition of mineral crystal on single, necrotic, degenerated tumor cells with progressive deposition on the outer layers, causing a 


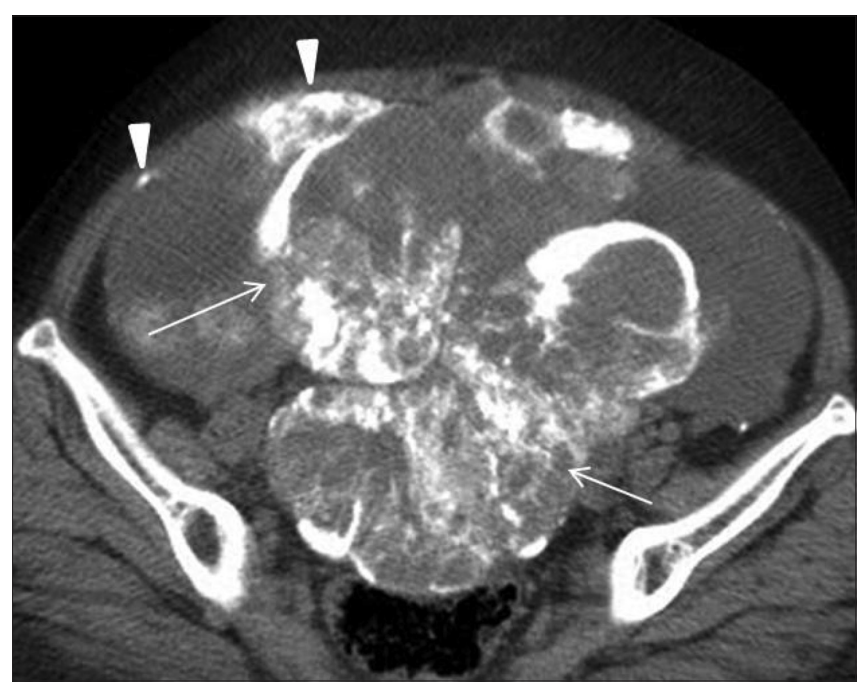

Figure 1: CT scan of the pelvis shows calcified ovarian mass lesions (arrows) in the pelvis, along with calcified peritoneal deposits (arrowheads)

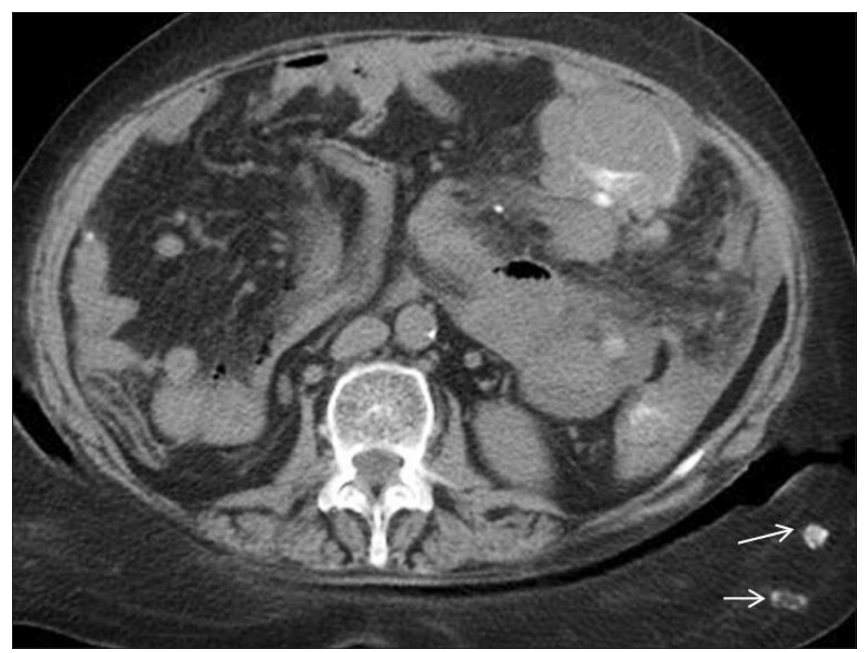

Figure 3: CT scan of the mid-abdomen shows subcutaneous deposits (arrows)

lamellated appearance. As these psammoma bodies are deposited in necrotic tumor cells, they may actually represent a growth halting process of the tumor and may act as a barrier for spread. In serous psammomacarcinoma of ovary, these psammoma bodies are associated with more than $75 \%$ epithelial cell clusters, with moderate cytological atypia and tissue or vessel invasion. ${ }^{[6]}$ Biochemically, CA 125 is an important marker for ovarian carcinoma and is commonly elevated. ${ }^{[2,7]}$

Clinically, these patients usually present with abdominal discomfort and increasing abdominal distension.

Radiologically, this tumor has classic and pathognomonic

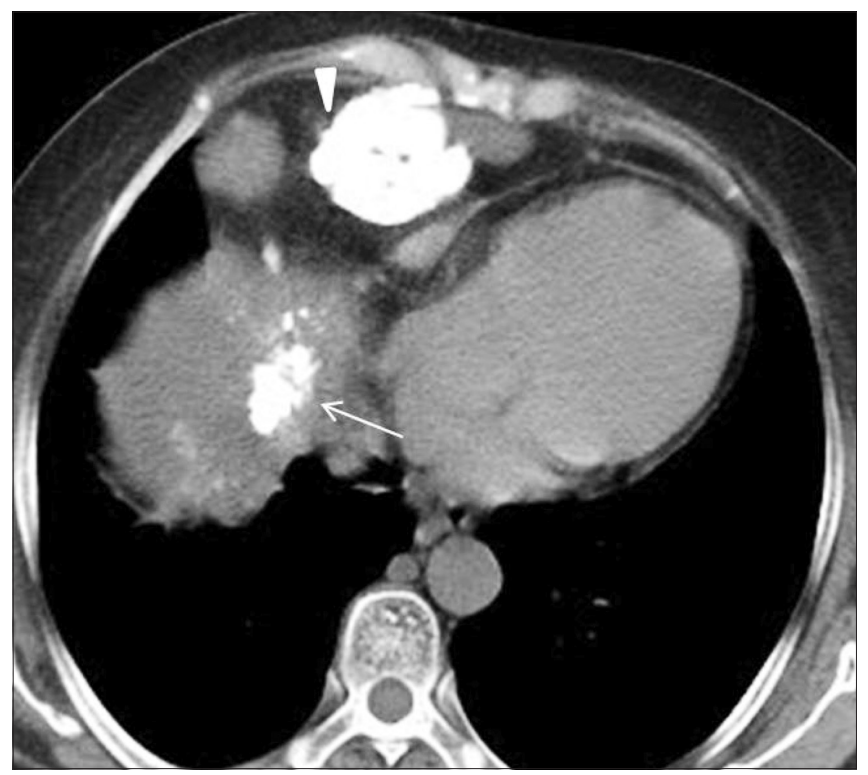

Figure 2: CT scan of the upper abdomen shows a calcified deposit (arrow) in a Morgagni hernia (arrowhead)

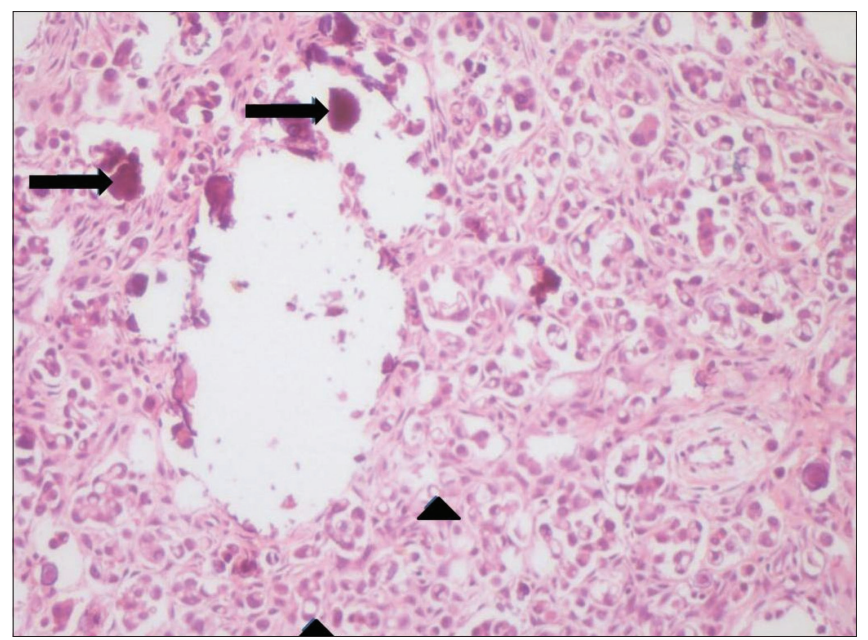

Figure 4: $\mathrm{H}$ and $\mathrm{E}$ with magnification shows psammoma bodies (black arrows) and signet ring cells (black arrowheads)

features. There are calcified lesions in one or both ovaries and, if there are peritoneal or distant metastases, then those lesions also show calcification. ${ }^{[8]}$ Some important conditions to be considered in the differential diagnoses of such multiple calcified lesions in abdomen are pseudomyxoma peritonei, undifferentiated abdominal malignancy, tuberculous peritonitis, meconium peritonitis, and mucinous adenocarcinoma of stomach..$^{[9]}$ Our patient also showed a mass arising from both ovaries as well as metastases to the peritoneum and liver surface, the ligamentum teres, the lesser sac, and both paracolic regions. In addition, our patient had a Morgagni hernia with a calcified deposit within it along with calcified deposits in the subcutaneous region, which have been only rarely described..$^{[1]}$ We 
presume that the subcutaneous lesion was a metastatic deposit, as similar subcutaneous metastatic deposits have been described earlier. ${ }^{[1]}$ Psammomacarcinoma has a better prognosis as compared to other carcinomas of the ovary. ${ }^{[7]}$ However, some reports have suggested a more aggressive behavior as well. ${ }^{[5,6]}$ Risk of recurrent disease following surgical resection is reported to be low. $\cdot^{[1]}$

\section{Conclusion}

Psammocarcinoma of ovary is a rare ovarian tumor with classic radiological findings of multiple calcified lesions in the abdomen and pelvis. The condition should be considered in the differential diagnosis when multiple calcified lesions are seen in the abdomen.

\section{References}

1. Chase DM, Sparks DA, Gener M, Smith J. A unique case of ovarian psammocarcinoma with mediastinal, pulmonary, subcutaneous and omental metastases. Arch Gynecol Obstet 2009;280:283-6.

2. Jain D, Akhila L, Kawatra V, Aggarwal P, Khurana N. Psammocarcinoma of ovary with serous cystadenofibroma of contralateral ovary: A case report. J Med Case Reports 2009;3:9330.
3. Rettenmaier MA, Goldstein BH, Epstein HD, Brown JV $3^{\text {rd }}$, Icha JP. Serous psammocarcinoma of the ovary: An unusual finding. Gynecol Oncol 2005;99:510-1.

4. Giordano G, Gnetti L, Milione M, Piccolo D, Soliani P. Serous psammocarcinoma of the ovary: A case report and review of literature. Gynecol Oncol 2005;96:259-62.

5. Gilks CB, Bell DA, Scully RE. Serous psammocarcinoma of the ovary and peritoneum. Int J Gynecol Pathol 1990;9:110-21.

6. Vimplis S, Williamson KM, Chaudry Z, Nuuns D. Psammocarcinoma of the ovary: A case report and review of the literature. Gynecol Surg 2006;3:55-7.

7. Poujade O, Uzan C, Gouy S, Pautier P, Duvillard P, Morice P. Primary psammocarcinoma of the ovary or peritoneum. Int J Gynecol Cancer 2009;19:844-6.

8. Hiromura T, Tanaka YO, Nishioka T, Tomita K. Serous psammocarcinoma of the ovary: CT and MR findings. J Comput Assist Tomogr 2007;31:490-2.

9. Dahnert W. Radiology review Manual. $5^{\text {th }}$ ed. philadelphia: Lippincott Williams and Wilkins; 2003. p. 748.

Cite this article as: Diwakar N, Kamble RB, Dixit J, Gangadhara DS, Shetty RV. Imaging of serous psammomacarcinoma of ovary with subcutaneous deposits: A case report. Indian J Radiol Imaging 2011;21:150-2.

Source of Support: Nil, Conflict of Interest: None declared.

\section{Staying in touch with the journal}

1) Table of Contents (TOC) email alert Receive an email alert containing the TOC when a new complete issue of the journal is made available online. To register for TOC alerts go to www.ijri.org/signup.asp.

\section{2) RSS feeds}

Really Simple Syndication (RSS) helps you to get alerts on new publication right on your desktop without going to the journal's website. You need a software (e.g. RSSReader, Feed Demon, FeedReader, My Yahoo!, NewsGator and NewzCrawler) to get advantage of this tool. RSS feeds can also be read through FireFox or Microsoft Outlook 2007. Once any of these small (and mostly free) software is installed, add www.ijri.org/rssfeed.asp as one of the feeds. 